\title{
PSYCHOLOGICAL APPROACH OF WITNESS AND JUDICIAL TESTIMONY
}

\author{
M. Pocora, M. S. Pocora
}

\section{Monica Pocora}

Faculty of Law, the Public and Private Law Department

"Danubius" University of Galati, Galati, Romania

*Correspondence: Monica Pocora, Danubius University, 3 Galați Blv., Galați, Romania

E-mail: monicapocora@univ-danubius.ro

\section{Mihail-Silviu Pocora}

Faculty of Economics, the Economy-Tourism-Services Department

"Tomis" University of Constanța, Constanța, Romania

*Correspondence: Silviu Pocora, Tomis University, 100 Petru Vulcan St., Constanța, Romania

E-mail: silviupocora@yahoo.com

\begin{abstract}
Testimony is one of the most important evidence, but in terms of doctrine and case, it appears a controversial approach to interpretation. This study aims to be an interdisciplinary approach, to highlight the psycho-legal elements, both of witness and testimony, elements of criminal procedural law. The method used in developing this approach is especially observation and managed by highlight, to connect the legal, criminal and psychological field in a delicate way.

Keywords: testimony, memory, error, false evidence

\section{Introduction}

Often, was proved that taking skeptical position faced to this testimonial element, the evidence, from many authors and practitioners, becomes a natural attitude. In support thereof, may occurs the existence of witnesses or persons aggrieved by bad faith, but also the existence of subjective data coming from sincere people who have the desire to testify accurate. Person obedience is rather complex to be analyzed very carefully in order to establish the truth. Although it is regarded as one of the most important evidence in doctrine and practice there is a skeptical position about this sample. A doubtful position against this evidence is based on the existence of witnesses or persons aggrieved by bad faith, but also the existence of subjective data coming from sincere people who have the desire to testify accurate. Thus, we are in an area where we must delimit between errors vs. lie, fidelity vs. honestly, because any mistake will have repercussions on who will be the subject of criminal liability. From this point of view there are differences between witnesses of good faith, even if perceived information in a different way.
\end{abstract}

\section{Psycho-Legal Aspects}

Evaluation of sample testimonials from supposed psychological result of interaction between physical characteristics of a person communicating information and facts perceived psychological peculiarities resulting in the truth. Thus, it should be reconstituted the process of testimony construction with all its stages, and the objective and subjective factors must be analyzed carefully because they influence the fidelity of testimony.

Defining testimony in judicial psychology perspective, we can say that is the result of observation and involuntary memory of a judicial fact, followed by its resumption in oral or 
written form, in front of prosecuting authorities and the courts ${ }^{1}$. Witness testimony must be investigated separately in all the aspects involved, implicit in psychological perspective, it is a logical research.

Thus, Enrico Altavilla in his work, "Psichologia giudiziaria" insists on the phenomenon of psychological testimony has a double aspect, subjective and objective: the individual's psychological capacity to testify, the possibility of an object or event to be the subject of testimony" 2 .

Thus, it must to take into account the following aspects:

a. Testimony is a characteristic of an judicial event to form the object of evidence, taking into account that some issues are excepted by testimonial evidence;

b. Memory means the object ability to be stored;

c. Fidelity means the individual capacity to remember judicial event and to submit a testimony;

d. Sincerity means the subjective available to say the truth.

\section{Criminological aspects}

Vidal and Magnol criminology studies revealed certain deficiencies fidelity of judicial testimony, namely fully faithful witness is an exception, a witness may be in error honest, extent and fidelity of judicial evidence diminishes proportionally with age reveals facts ${ }^{3}$; value is proportional to the number of depositions of witnesses and a minority may be right against a strong majority, a large number of anomalous, unknown as such are heard as witnesses and distort the truth due to disturbances and personal handicaps ${ }^{4}$.

\section{Doctrine}

As regards the probative value of the testimony, in theory there were many opinions. Thus, the testimony with witness being easiest way of administer and evaluate was sometimes viewed with distrust, skepticism, so the credibility of this evidence was diminished.

A similar opinion ${ }^{5}$ said that the sample testimonial is apparently fragile, sometimes misleading and a rather random.

In literature, there is the conclusion that the witness is a passage of reality through the filter of witnesses subjectivity, but also that of the judicial body that considers the probative value of the witness statements, given that there are certain causes of relativity testimony ${ }^{6}$ among which the most important are: imperfect senses, mental processes distorted, quasigeneral conviction (that witness statements should be a faithful reproduction of reality).

\section{Relationship witness-judge of psychological view}

In the testimony process is created a trial relationship, the witness - judge, although it is a legal relationship, it is also a psychological relationship between the witness and judge, a cerebral communication with procedural compliance. Legal relationship, witness-judge, is fundamental for judiciary underlying procedural activities to identify, manage, appreciation and use of the evidence in order to solve judicial cases, regardless of their nature. Prerequisite of brain intercommunication between witness and judge is the witness to be in good faith, to overcome fear, interest or indifference, and the judge to help him to gain courage and responsibility necessary to establish the truth.

\section{Psychological approach of judicial testimony of good faith}

Judicial psychology provides methods and criteria for justice to detect some false or misleading testimony, of good faith, but also the false witness, of bad faith.

\footnotetext{
${ }^{1}$ Stancu, E. (2002). "Tratat de Criminalistică", Bucharest, "Universul Juridic" Publishing House;

${ }^{2}$ Mitrofan, N; Zdrenghea, V.; Butoi, T., (2000), Psihologie Judiciară, Bucharest, "Şansa” Publishing House;

${ }^{3}$ Sutherland, H.E.; Cressey. (1996 ), Principii de criminology, R.D.Paris;

${ }^{4}$ Revue de Droit Penal et de Criminologie, no.6., 1976;

${ }^{5}$ Bogdan, T. (1973). "Probleme de psihologie judiciară". Bucharest, "Stiințifică" Publishing House;

${ }^{6}$ Stancu, E. (2002). "Tratat de Criminalistică". Bucharest, "Universul Juridic" Publishing House.
} 
Good faith is the testimony of witnesses who made oath, is not false it not comes from dishonesty of witness and thus not covered by criminal law. Some of the testimonials of good faith can have the same consequences as testimony of bad faith, namely the false testimony. Analyzing this testimony from psychological view is most important for practitioners of the judiciary.

\section{General aspects of psychological approach of testimony of good faith}

In a criminal trial witnesses can testify to various inconsistent with reality namely the false confessions that are detrimental to justice. With judicial psychology support, can detect false confessions, but of good faith and false witness who violates the principle of good faith, of honesty. False testimony is regulated by Art 260 Criminal code both with offenses against carrying out justice.

Usually, withdrawal of false testimony is challenged and, rarely, it is the result of selfdenunciation who has made false, so a voluntary initiative ${ }^{7}$. In practice judicial authorities in this matter, arise that promote withdrawal of false testimony is result of procedural activities of analysis and evaluation of the testimony complained that emphasize logical conclusions about that testimony cannot be given credibility, being suspected of untruth.

\section{Witness conduct}

According to its nature, it is considered that the witness has a relatively constant expression. Therefore, it is good to know witness orientations to sincerity, honesty, fairness, humility, generosity or by selfishness, cowardice etc. Knowledge of witness in terms of its features is a necessary but insufficient condition because witness testimony may be untrue even if they come from people with strong morals. Another credibility element is the affiliation to one of psychological types fidelity testimony is psychologically dependent on this type belonging to witness.

\section{Conclusions}

1. Testimonial evidence shows a growing interest burden of proof. On a comparison with other evidences, we could even say that it is the most comprehensive in the sense that the statement of a witness, the court may issue a final judgment of conviction, while a statement of any other participant, does not cause such a decision.

2. Equally, we believe that is a complex approach in terms of prospects. Thus, due to the development and presentation of the study, it was observed that the role of the witness in a criminal trial is both probes (private elements that transmit findings provide private) and deductive (general to offer items that can extract individual elements).

3. The most important proposals resulting from browsing this study are the following:

- establishment of an applied Psychology inside of courts and its including in the forerunner measures of trial;

- decrease of witness trust, based on complex structure of psychological testimony.

\section{Bibliography}

Durnescu, I., Haines, K., Probation in Romania: Archaeology of a Partnership, in The British Journal of Criminology, 2012;

Dongoroz, V., \& colab., Explicații teoretice ale Codului penal roman, C.H. Beck Publishing House, Bucharest, 2003; 2002;

Stancu, E., Tratat de Criminalisticăa ,"Universul Juridic” Publishing House, Bucarest,

Mitrofan, N.; Zdrenghea, V.; Butoi, T., Psihologie Judiciară,, "Şansa” Publishing House, Bucarest, 2000;

\footnotetext{
${ }^{7}$ Durnescu, I., Haines, K. (2012). Probation in Romania: Archaeology of a Partnership. The British Journal of Criminology.
} 
Sutherland, E.; Cressey D. R., Principes de criminology, Cujas Publishing House, Paris, 1966;

R.D.Paris, Revue de Droit Penal et de Criminologie, no.6, 1976;

Bogdan, T., Probleme de psihologie judiciară, "Editura Stiințifică” Publishing House, Bucarest, 1973;

Roşca A., Metodologie şi tehnici experimentale în psihologie, "Editura Ştiinţifică" Publishing House, Bucarest, 1971. 